\title{
PENGARUH MODEL PEMBELAJARAN GROUP INVESTIGATION BERBASIS PROYEK TERHADAP HASIL BELAJAR IPA SISWA KELAS IV
}

\author{
Pande Putu Yustika Dewi1,*, IB Surya Manuaba² , Ni Wayan Suniasih ${ }^{3}$ \\ 1 Jurusan Pendidikan Guru Sekolah Dasar Universitas Pendidikan Ganesha \\ ${ }^{2}$ Jurusan Pendidikan Guru Sekolah Dasar Universitas Pendidikan Ganesha \\ 3 Jurusan Pendidikan Guru Sekolah Dasar Universitas Pendidikan Ganesha
}

\section{Abstrak}

Penelitian ini bertujuan untuk mengetahui perbedaan yang signifikan hasil belajar IPA antara kelompok siswa yang dibelajarkan menggunakan model pembelajaran kooperatif tipe Group Investigation berbasis proyek dan kelompok siswa yang dibelajarkan menggunakan pembelajaran konvensional siswa kelas IV SD Gugus 1 Abiansemal tahun ajaran 2016/2017. Populasi penelitian adalah siswa kelas IV SD Gugus 1 Abiansemal tahun ajaran 2016/2017 sebanyak 126 siswa. Sampel penelitian menggunakan teknik random sampling. Sampel penelitian ini adalah kelas IV SD Negeri 3 Blahkiuh sebagai kelompok eksperimen dan kelas IV SD Negeri 2 Sangeh sebagai kelompok kontrol. Data hasil belajar IPA dikumpulkan dengan instrumen berupa tes pilihan ganda, kemudian dianalisis dengan uji-t. Hasil analisis menunjukkkan hasil thitung $=3,6331>t_{\text {tabel }}=2,000$ pada taraf signifikansi $5 \%$ dengan $\mathrm{dk}=60$. Oleh karena thitung 3,6331> tabel 2,000maka Hodi tolak dan $\mathrm{H}_{\mathrm{a}}$ diterima. Demikian pula nilai rata-rata hasil belajar IPA siswa kelompok eksperimen $\bar{X}_{1}=$ $82,05>\bar{X}_{2}=73,73$ rata-rata hasil belajar IPA siswa kelompok kontrol. Dapat disimpulkan bahwa penerapan model pembelajaran kooperatif tipe Group Investigation berbasis proyek berpengaruh terhadap hasil belajar IPASiswa kelas IV SD Gugus 1 Abiansemal tahun ajaran 2016/2017.
\end{abstract}

Keywords:

group investigation, proyek, IPA

\section{PENDAHULUAN}

Pendidikan adalah proses pembentukan kemampuan dasar yang fundamental yang menyangkut daya pikir (intelektual) maupun daya rasa (emosi) manusiam (Wisnawa, Renda, \& Widiana, 2016). Pendidikan juga merupakan sarana penting untuk meningkatkan kualitas sumber daya manusia (SDM) dalam menjamin keberlangsungan pembangunan suatu bangsa. Pendidikan memberikan kemungkinan pada siswa untuk memperoleh kesempatan, harapan dan pengetahuan agar dapat hidup secara lebih baik. Menurut Darmadi (dalam Sugiyanto, 2015) di dalam pembelajaran, guru memiliki peran penting dalam mengkondisikan lingkungan agar menunjang terjadinya perubahan perilaku bagi peserta didik. Salah satu muatan pembelajaran di sekolah dasar yaitu Ilmu Pengetahuan Alam (IPA). Pembelajaran IPA di Sekolah Dasar sangat penting bagi siswa, karena dengan memberikan pelajaran IPA di sekolah dasar, maka siswa dapat menguasai pengetahuan, fakta, konsep, prinsip, proses penemuan, serta memiliki sikap ilmiah, yang akan bermanfaat bagi siswa dalam mempelajari diri dan alam sekitar. Tujuan IPA di sekolah dasar berkaitan dengan cara mencari tahu secara sistematis sehingga IPA bukan hanya penguasaan kumpulan pengetahuan yang berupa fakta-fakta, konsep-konsep atau prinsip-prinsip saja tetapi juga merupakan suatu proses penemuan yang diiringi dengan pengembangan sikap ilmiah. Oleh karena itu, sebaiknya pembelajaran IPA di sekolah dasar lebih menekankan aspek proses bagaimana siswa belajar yaitu dengan memberikan pengalaman pada siswa secara langsung melalui percobaan yang melibatkan keaktifan siswa, baik aktivitas fisik maupun aktivitas mental, menanamkan pada siswa pentingnya sikap ilmiah dalam pembelajaran IPA agar produk yang dihasilkan dapat

\footnotetext{
* Corresponding author.

E-mail Addresses: yustikadewipande@yahoo.co.id (Pande Putu Yustika Dewi), ibsm.co.id@gmail.com (IB Surya Manuaba)

niwayan.suniasih@undiksha.ac.id (Ni Wayan Suniasih)
} 
dipertanggungjawabkan, serta memberikan media dan sumber belajar yang menarik pada siswa sehingga pembelajaran berlangsung menyenangkan dan secara tidak langsung membangkitkan keingintahuan siswa terhadap materi yang akan diajarkan (Susanti, Darsana \& Ardana, 2013)

Berdasarkan hasil observasi dan wawancara dengan guru kelas IV di semua SD di Gugus 1 Abiansemal bahwa, prestasi belajar siswa khususnya pada muatan materi IPA di SD Gugus 1 Abiansemal belum dapat dicapai secara optimal dan masih perlu adanya peningkatan dan inovasi dalam proses pembelajaran. Hal tersebut dikarenakan proses pembelajaran di SD Gugus 1 Abiansemal cenderung menggunakan pembelajaran konvensional. Dalam hal ini pembelajaran konvensional yang dimaksudkan adalah pembelajaran dengan menggunakan medote ceramah, yaitu pembelajaran yang lebih banyak didominasi gurunya sebagai pentransfer ilmu, sementara siswa lebih pasif sebagai penerima ilmu. Hal ini membuat siswa kurang termotivasi dan cepat merasa bosan dalam menerima pembelajaran. Proses pembelajaran seperti ini dapat mengakibatkan pembelajaran menjadi kurang bermakna dan siswa menjadi kurang paham dengan muatan materi yang dipelajari.Pengajaran IPA di sekolah dasar hendaknya membuka kesempatan untuk memupuk rasa ingin tahu siswa secara alamiah. Hal ini akan membantu mereka mengembangkan kemampuan bertanya dan mencari jawaban atas berdasarkan bukti serta mengembangkan cara berpikir ilmiah.

Hal ini juga sejalan dengan hasil penelitiannya Wardana dkk (2013) yang menyataka bahwa penyebab rendahnya mutu pendidikan khususnya mutu pendidikan IPA adalah kurangnya variasi model pembelajaran yang inovatif yang dilakukan oleh guru dalam melakukan proses belajar mengajar. Begitu juga Amiruddin (2014) yang menyatakan bahwa prestasi belajar siswa masih kurang, hal itu disebabkan karena siswa suka membuang waktu, dan kurang bergairah dalam melaksanakan tugas. Selain itu juga guru lebih sering menggunakan metode ceramah.

Berkaitan dengan kenyataan tersebut, guru seharusnya melakukan inovasi dalam proses pembelajaran sehingga peran guru dalam pembelajaran harus bergeser menjadi, 1) perancang pembelajaran agar siswa aktif mencari pengetahuan baru dan 2) fasilitator atau mediator untuk belajar. Model pembelajaran yang digunakan sebaiknya lebih melibatkan siswa dalam proses pembelajaran serta pemecahan masalah yang dihadapi dalam pembelajaran, sehingga siswa selalu aktif dalam proses pembelajaran. Salah satu model pembelajaran yang dapat digunakan dalam proses pembelajaran adalah model pembelajaran kooperatif tipe Group Investigation berbasis proyek. Model pembelajaran kooperatif tipe GI adalah salah satu bentuk model pembelajaran kooperatif yang memiliki titik tekan pada partisipasi dan aktifitas siswa untuk mencari sendiri materi atau segala sesuatu mengenai materi pelajaran yang akan dipelajari. Metode group investigation salah satu metode spesialisasi tugas yang memberikan kesempatan pada siswa untuk mengembangkan kreativitas dan produktivitas berpikirnya (Wulandari, 2010). Model ini harus melibatkan siswa mulai dari perencanaan, baik dalam menentukan topik maupun cara untuk mempelajarinya melalui investigasi. Muliyantini dan Parmiti (2017) menemukan bahwa terdapat penerapan model pembelajaran Group Investigation (GI) dapat efektif meningkatkan hasil belajar IPA, materi sifat bahan dan struktur penyusunnya pada siswa kelas V SD No. 1 Abianbase. Hal ini terlihat pada siklus I hasil belajar siswa $66,67 \%$ berada pada kategori sedang. Pada siklus II hasil belajar siswa $90,91 \%$ berada pada kategori sangat tinggi. Terjadi peningkatan hasil belajar siswa sebesar $24,24 \%$ dari siklus I ke siklus II. Hasil-hasil penelitian tentang GI menyarankan bahwa dalam proses pembelajaran hendaknya menerapkan model pembelajaran Group Investigation (GI) agar membantu pembentukkan karakter bersahabat dan peningkatan hasil belajar siswa (Zainuddin, 2013).

Langkah-langkah pembelajaran pada model pembelajaran group investigation sebagai berikut (Almuniar, 2015): (1) Guru membagi kelas menjadi beberapa kelompok yang heterogen, (2) Guru menjelaskan maksud pembelajaran dan tugas kelompok yang harus dikerjakan, (3) Guru memanggil ketua ketua kelompok untuk menjelas kan materi tugas secara kooperatif dalam kelompoknya, (4) Masing masing kelompok membahas materi tugas secara kooperatif dalam kelompoknya, (5) Setelah selesai, masing masing kelompok di wakili ketua kelompok atau salah satu anggotanya menyampaikan hasil pembahasannya, (6) Kelompok lain dapat memberi tanggapan terhadap hasil pembahasannya, (7) Guru memberi penjelasan singkat (klarifikasi) bila terjadi kesalahan konsep dan memberikan kesimpulan, (8) Evaluasi

Untuk mendukung peningkatan hasil belajar siswa dalam penerapan model pembelajaran kooperatif tipe GI ini salah satu metode yang dapat digunakan adalah dengan menerapkan pembelajaran berbasis proyek. Pembelajaran berbasis proyek merupakan pembelajaran yang mengembangkan pemahaman konsep melalui investigasi masalah yang bermakna sehingga siswa dapat menghasilkan suatu produk nyata. Pembelajaran ini memungkinkan siswa untuk mengembangkan kreativitasnya dalam merancang dan membuat proyek yang dapat dimanfaatkan untuk mengatasi permasalahan. 
Berdasarkan uraian tersebut, maka dilakukan penelitian yang berjudul "Pengaruh Model Pembelajaran Kooperatif Tipe Group Investigation Berbasis Proyek Terhadap Hasil Belajar IPA Siswa Kelas IV SD Gugus 1 Abiansemal Tahun Ajaran 2016/2017".

\section{METODE}

Pelaksanaan penelitian dilakukan di SDGugus 1 Abiansemal. Waktu penelitian terkait dengan penelitian ini dilaksanakan selama 3 bulan mulai Maret sampai dengan Mei 2017, perlakuan sebanyak 6 kali di kelompok eksperimen dan 6 kali di kelompok kontrol. Jumlah perlakuan yang diberikan telah disesuaikan dengan jam pelajaran, dan materipembelajaran yang telah diatur dalam kurikulum dan silabus.

Jenis penelitian yang digunakan dalam penelitian ini adalah eksperimen semu(quasi eksperiment) dengan menggunakan desain penelitian nonequivalent control group design. Desain ini memiliki kelompok kontrol, tetapi tidak bisa sepenuhnya mengontrol variabel-variabel luar yang mempengaruhi pelaksanaan eksperimen. Hal ini dikarenakan kemampuan peneliti dalam mengamati perilaku siswa sangat terbatas terutama ketika siswa berada di luar sekolah (rumah), peneliti juga tidak memiliki kemampuan untuk mengetahui persepsi siswa terhadap perlakuan secara pasti.

Pada desain ini, baik kelompok eksperimen maupun kelompok kontrol dibandingkan. Pretest diberikan untuk kelompok kontrol dan kelompok eksperimen. Setelah itu peneliti memberikan perlakuan, yaitu dengan memberikan model kooperatif tipe GI berbasis proyek kepada kelompok eksperimen dan memberikan pembelajaran konvensional kepada kelompok kontrol. Kemudian setelah diberikan perlakuan, dilakukan posttest untuk mengetahui hasil belajar IPA.

Populasi adalah keseluruhan objek yang tinggal bersama dalam satu tempat yang mempunyai kualitas dan karakteristik tertentu yang ditetapkan oleh peneliti untuk dipelajari dan kemudian ditarik kesimpulannya. Populasi dari penelitian ini adalah seluruh siswa kelas IV SD Gugus 1 Abiansemal tahun ajaran 2016/2017, yang terdiri dari 5 kelas dalam 5 sekolah dasar. Jumlah populasi dari penelitian ini adalah 126siswa.

Sampel adalah bagian dari jumlah dan karakteristik yang dipilih untuk mewakili seluruh populasi dan diambil dengan menggunakan teknik tertentu. Teknik pengambilan sampel pada penelitian ini adalah Random Sampling. Pada penelitian ini yang dirandom adalah kelasnya, sehingga setiap kelas mendapatkan peluang yang sama untuk menjadi sampel penelitian.Pemilihan sampel penelitian ini tidak dilakukan pengacakan individu melainkan hanya pengacakan kelas. Karena tidak bisa mengubah kelas yang telah terbentuk sebelumnya.Kelas dipilih sebagaimana telah terbentuk tanpa campur tangan peneliti dan tidak dilakukannya pengacakan individu, kemungkinan pengaruh-pengaruh dari keadaan siswa mengetahui dirinya dilibatkan dalam eksperimen dapat dikurangi sehingga penelitian ini benar-benar menggambarkan pengaruh perlakuan yang diberikan.

Untuk mendapatkan kelas yang setara dari segi akademik, dari seluruh populasi kelas yang tersedia dilakukan pengundian. Cara pengundian dilakukan dengan menulis semua nama kelas IV di seluruh SD Negeri populasi pada masing-masing kertas yang jumlahnya 5 kelas, kemudian kertas digulung. Gulungan kertas dimasukkan ke dalam kotak dan dikocok. Ambil satu gulungan kertas, lalu ambil satu gulungan kertas lain, tanpa memasukkan kembali gulungan kertas pertama. Nama-nama SD pada kedua gulungan kertas tersebut merupakan sampel penelitian. Setelah mendapatkan 2 kelasyang diperoleh dari hasil pengundian, selanjutnya 2 kelas yang terpilih diberikan pretest untuk penyeteraan kelompok. Teknik yang digunakan dalam penyeteraan kelompok adalah teknik matching. Setelah diperoleh beberapa pasangan yang memiliki nilai yang sama atau nilai yang berdekatan maka kedua sampel dikatakan setara. Selanjutnya dilakukan pengundian untuk pemilihan kelas eksperimen dan kelas kontrol.

Setelah didapatkan pasangan dengan nilai yang sama maka 2 kelas tersebut dikatakan setara.Teknik pengambilan sampel yang telah dilakukan jatuh pada kelas IV SD Negeri 2 Sangeh dan IV SD Negeri 3 Blahkiuh. Berdasarkan hasil penyetaraan yang telah dilakukan terdapat 31 pasang siswa yang memiliki nilai yang sama, sehingga sampel yang gunakan dalam penelitian ini berjumlah 62 orang siswa, yaitu 31 orang siswa dari SD Negeri 3 Blahkiuh sebagai kelompok eksperimen dan 31 orang siswa dari SD Negeri 2 Sangeh sebagai kelompok kontrol. 


\section{HASIL DAN PEMBAHASAN}

Data hasil belajar IPA diperoleh dari hasil posttest yang diberikan pada akhir penelitian. Teknik pengumpulan data dalam penelitian ini menggunakan metode tes. Tes yang akan digunakan untuk mengukur hasil belajar IPA berupa tes objektif dalam bentuk pilihan ganda biasa. Sebelum siswa diberikan posttest, terlebih dahulu dilakukan pengujian instrumen yaitu uji validitas, reliabilitas, daya beda dan indeks kesukaran. Selanjutnya setekah diperoleh hasil posttest, data hasil belajar siswa dianalisis menggunakan uji-t. Deskripsi data hasil belajar IPA siswa yang dipaparkan meliputi nilai mean (ratarata),standar deviasi, dan varians.

Uji prasyarat dilakukan terlebih dahulu sebelum uji hipotesis menggunakan uji-t. Uji prasyarat tersebut meliputi uji normalitas dan uji homogenitas varians diuraikan berikut ini.

Uji normalitas dilakukan untuk mengetahui sebaran frekuensi skor, untuk menguji data hasil belajarIPA kelompok eksperimen dan kontrol adalah dengan rumus Chi-Kuadrat. Kriteria pengujian pada uji normalitas adalah jika $\mathrm{x}^{2}$ hitung $<\mathrm{x}^{2}$ tabel maka sebaran data kedua kelompok berdistribusi normal. Berdasarkan hasil uji normalitas kelompok eksperimen, diperoleh Chi-Kuadrat hitung $\left(\mathrm{x}^{2}\right.$ hitung $\left.=1,826\right)$ kemudian nilai tersebut dibandingkan dengan Chi-Kuadrat tabel dengan taraf signifikansi $5 \%$ dan dk 5 $\left(x^{2}\right.$ tabel $\left.=11,070\right)$. Hal ini menunjukkan bahwa $x^{2}$ hitung $<x^{2}$ tabel berarti data hasil belajarIPA kelompok eksperimen berdistribusi normal. Berdasarkan hasil uji normalitas kelompok kontrol, diperoleh ChiKuadrat hitung $\left(\mathrm{x}^{2}\right.$ hitung $\left.=2,417\right)$ kemudian nilai tersebut dibandingkan dengan Chi-Kuadrat tabel $\left(\mathrm{x}^{2}\right.$ tabel= 11,070). Hal ini menunjukkan bahwa $x^{2}$ hitung $<x^{2}$ tabel berarti data hasil belajarIPA kelompok kontrol berdistribusi normal.

Pengujian homogenitas varians antar kelompok dimaksudkan untuk meyakinkan bahwa perbedaan yang diperoleh uji-t benar-benar berasal dari perbedaan antar kelompok bukan disebabkan oleh perbedaan di dalam kelompok. Uji homogenitas varians yang dilakukan dalam penelitian ini menggunakan uji-F dari Havley. Dari hasil analisis, diperoleh $\mathrm{F}_{\text {hitung }} 1,07$ dan $\mathrm{F}_{\text {tabel }} 1,79$. Hal ini berarti $\mathrm{F}_{\text {hitung }}<\mathrm{F}_{\text {tabel }}$, sehingga data kedua kelompok memiliki varians yang homogen. Berdasarkan hasil uji prasyarat yang terdiri dari uji normalitas dan uji homogenitas varians, disimpulkan bahwa data kedua kelompok sampel ialah berdistribusi normal dan memiliki varians yang homogen. Dengan demikian, uji hipotesis menggunakan uji-t dapat dilakukan.

Nilai mean atau rata hasil belajar IPA siswa yang mengikuti model pembelajaran kooperatif tipe GI berbasis proyek, yaitu $\bar{X}=82,05$ dengan standar deviasi 3,02 dan varians 83,92, sedangkan nilai mean atau rata hasil belajar IPA siswa yang mengikuti model pembelajaran konvensional, yaitu $\bar{X}=73,73$ denganstandar deviasi 2,97 dan varians 78,23. Perhitungan analisis data hasil penelitian yang diperoleh menunjukkan bahwa hasil belajar IPA siswa yang dibelajarkan menggunakan model pembelajaran kooperatif tipe GI berbasis proyek memiliki nilai mean lebih tinggi daripada siswa yang mengikuti pembelajaran konvensional yaitu $\bar{X}=82,05>\bar{X}=73,73$.

Hipotesis yang diuji dalam penelitian ini adalah tidak terdapat perbedaan yang signifikan hasil belajar IPAkelompok siswa yang dibelajarkan melalui model pembelajaran Koopertif Tipe GI berbasis proyek dengan kelompok siswa yang dibelajarkan melalui pembelajaran konvesional pada kelas IV SD Gugus 1 AbiansemalTahun Pelajaran 2016/2017.Hasil uji prasyarat yang meliputi uji normalitas dan homogenitas varians yang dilakukan dalam penelitian ini diperoleh kedua kelompok sampel berdistribusi normal dan memiliki varians yang homogen. Analisis statistik yang digunakan untuk menguji hipotesis penelitian ini adalah uji-t dengan separated varians. Berdasarkan hasil uji hipotesis di peroleh $t_{\text {hitung }}=3,6331$ sedangkan pada taraf signifikansi $5 \%$ dan $d k=n 1+n 2-2=(31+31-2)=60$ diperoleh nilai $t_{\text {tabel }}=2,000$. Oleh karena thitung 3,6331> $t_{\text {tabel }}$ 2,000maka $H_{0}$ di tolak dan $H_{a}$ diterima. Perhitungan selengkapnya terlampir pada lampiran. Rekapitulasi hasil analisis uji-t kelompok sampel penelitian ini disajikan dalam tabel 4.5 berikut ini.

Tabel 4.5Rekapitulasi Hasil Analisis Data Hasil Belajar IPA Menggunakan Uji-t

\begin{tabular}{llccccccl}
\hline No & Sampel & $\mathrm{N}$ & $\mathrm{Dk}$ & Mean & Varians & $\mathrm{t}_{\text {hitung }}$ & $\mathrm{t}_{\text {tabel }}$ & Status \\
\hline 1 & Kelompok eksperimen & 31 & 60 & 82,05 & 83,295 & \multirow{2}{*}{3,6331} & 2,000 & $\mathrm{H}_{0}$ \\
2 & Kelompok kontrol & 31 & & 73,73 & 78,239 & & & \\
\hline
\end{tabular}

Berdasarkan hasil uji hipotesis di peroleh $t_{\text {hitung }}=3,6331$ sedangkan pada taraf signifikansi $5 \%$ dan $d \mathrm{k}=\mathrm{n} 1+\mathrm{n} 2-2=(31+31-2)=60$ diperoleh nilai $t_{\text {tabel }}=2,000$. Oleh karena $t_{\text {hitung }} 3,6331>t_{\text {tabel }} 2,000$ $\mathrm{H}_{0}$ di tolak dan $\mathrm{H}_{\mathrm{a}}$ diterima. Hal ini berarti terdapat perbedaan yang signifikan hasil belajar IPA kelompok 
siswa yang dibelajarkan melalui model pembelajaran koopertif tipe GI berbasis proyek dan siswa yang mengikuti pembelajaran konvensional. Perolehan hasil perhitungan analisis data yang dilakukan menunjukkan bahwa nilai rata-rata siswa yang mengikuti model pembelajaran kooperatif tipe GI berbasis proyek $(\bar{X}=82,05)$ dan siswa yang mengikuti pembelajaran konvensional $(\bar{X}=73,73)$. Dengan demikian, terdapat perbedaan yang signifikan hasil belajar IPA siswa yang dibelajarkan melalui model pembelajaran kooperatif tipe GI berbasis proyek dengan kelompok siswa yang dibelajarkan melalui pembelajaran konvesional pada kelas IV SD Gugus 1 AbiansemalTahun Pelajaran 2016/2017.

Berdasarkan hasil temuan tersebut, dapat dinyatakan kedua kelompok sampel penelitian yang memiliki kemampuan setara, setelah diberikan perlakuan berupa pembelajaran dengan menggunakan model pembelajaran kooperatif tipe GI berbasis proyek dan mengikuti pembelajaran konvensional diperoleh hasil belajar yang berbeda. Hal ini dapat dilihat juga dari rata-rata yang diperoleh $\bar{X}=82,05$ siswa yang mengikuti pembelajaran menggunakan model pembelajaran kooperatif tipe GI berbasis proyek lebih tinggi dibandingkan dengan rata-rata yang diperoleh $\bar{X}=73,73$ siswa yang mengikuti pembelajaran konvensional. Perbedaan hasil belajar dengan perolehan nilai rata-rata yang lebih tinggi pada kelompok eksperimen dibandingkan kelompok kontrol disebabkan oleh perlakuan berupa model pembelajaran kooperatif tipe $G I$ berbasis proyek pada kelompok eksperimen.

Pada kelas eksperimen, proses pembelajaran menggunakan model pembelajaran koopertif tipe GI berbasis proyek, pembelajaran ini menenkankan pada partisipasi dan aktivitas siswa untuk mencari sendiri materi atau segala sesuatu mengenai materi pelajaran yang akan dipelajari sehingga siswa terlibat secara langsung dan aktif dalam proses pembelajaran mulai dari perencanaan, menentukan topik yang akan dipelajari, melakukan investigasi serta menyiapkan dan menyajikan laporan. Hal tersebut mengarahkan siswa untuk memiliki kemampuan yang baik dalam berkomunikasi maupun dalam keterampilan proses kelompok. Selain dengan model koopertif tipe GI, pembelajaran berbasis proyek sangat penting untuk dimunculkan pada saat proses pembelajaran. Pembelajaran berbasis proyek merupakan sebuah metode pembelajaran yang mengembangkan pemahaman konsep melalui investigasi masalah sehingga melibatkan siswa untuk mengerjakan sebuah proyek mulai dari membuat perencanaan, berkomunikasi, menyelesaikan masalah, membuat keputusan dan mempresentasikan produk yang telah dibuat, sehingga akhir dari pembelajaran ini berupa produk. Berbeda pada kelompok kontrol, pembelajaran yang digunakan adalah pembelajaran secara konvensional, yakni dengan menggunakan metode ceramah, penugasan serta tanya jawab. Hal tersebut membuat siswa merasa kurang bersemangat dan cepat merasa bosan dalam belajar karena pembelajaran masih banyak ceramah dan pembelajaran bersifat satu arah.

Sejalan dengan penjelasan di atas, menurut Sudarsono (dalam Sutrini, Suarni, \& Renda, 2013) bahwa kelebihan yang dimiliki oleh model GI ini adalah 1) pelaksanaan pembelajaran tidak bergantung pada usia siswa, 2) siswa menjadi lebih terangsang dan lebih aktif pada saat mengikuti pembelajaran hal ini disebabkan karena adanya rasa kebersamaan dalam kelompok, 3) siswa menjadi lebih bersemangat dan berani mengemukakan pendapat pada saat berdiskusi dalam kelompok, 4) dengan adanya pembelajaran kooperatif ini siswa menjadi lebih termotivasi untuk belajar, 5) dapat meningkatkan motivasi yang tinggi kepada siswa pada saat pembelajaran karena adanya tuntutan dalam menyelesaikan tugas. Menurut Aziar (2016) penerapan model kooperatif tipe GI dengan media CD pembelajaran meningkatkan kualitas pembelajaran IPA yaitu pada keterampilan siswa, dan hasil belajar. Model kooperatif tipe GI dengan media CD pembelajaran dapat dijadikan acuan guru sebagai solusi untuk meningkatkan kualitas pembelajaran pada mata pelajaran IPA.

Penelitian ini juga diperkuat oleh penelitian yang relevan, yakni yang telah dilaksanakan oleh, Suarni (2014) yang memaparkan rerata hasil belajar IPA siswa yang mengikuti pembelajaranberbasis projek lebih besar dibandingkan dengan hasil belajar IPA siswa yang mengikuti pembelajaran konvensional. Hal tersebut dapat dilihat dari nilai rata-rata hasil belajar IPA siswa yang mengikuti pembelajaran berbasis projek sebesar 79,15 sedangkan hasil belajar IPA siswa yang mengikuti pembelajaran konvensional adalah 71,50. Selain itu, didukung pula oleh penelitian yang telah dilaksanakan oleh Wiryarta (2014), dipaparkan bahwa hasilbelajar IPA yang mengikuti model pembelajaran kooperatif tipe group investigation berbasis proyek yaitu 79,03 sedangkan rata-rata hasil belajar IPA siswa yang mengikuti pembelajaran konvensional adalah 71,70. Keberhasilan penelitian ini didukung pula oleh Wisnawa, Renda, Widiana (2016) bahwa terjadi peningkatan hasil belajar siswa pada mata pelajaran IPA melalui penerapan model pembelajaran kooperatif tipe GI (Group Investigation) pada siswa kelas IV SD Negeri 4 Penarukan, Kecamatan Buleleng, Kabupaten Buleleng tahun pelajaran 2016/2017. Berdasarkan tes hasil belajar IPA, persentase rata-rata hasil belajar IPA siswa pada siklus I sebesar 71,12\% dengan kategori sedang, dan persentase rata-rata hasil belajar IPA siswa pada siklus II 
sebesar $81,30 \%$ dengan kategori tinggi. Hasil penelitian menunjukkan bahwa terjadi peningkatan persentase hasil belajar pada siswa kelas IV SD Negeri 4 Penarukan.

\section{SIMPULAN dan SARAN}

Berdasarkan urain di atas maka dapat disimpulkan model pembelajaran kooperatif tipe GI berbasis proyek berpengaruh terhadap hasil belajar IPA Siswa Kelas IV SD Gugus 1 Abiansemal tahun ajaran 2016/2017, hal ini terbukti dari hasil analisis diketahui bahwa sebaran data hasil belajar IPA siswa berdistribusi normal dan memiliki varians yang homogen. Berdasarkan hasil uji hipotesis di peroleh $\mathrm{t}_{\text {hitung }}=3,6331$ sedangkan pada taraf signifikansi $5 \%$ dan $\mathrm{dk}=\mathrm{n} 1+\mathrm{n} 2-2=(31+31-2)=60$ diperoleh nilai $t_{\text {tabel }}=2,000$. Oleh karena $t_{\text {hitung }} 3,6331>t_{\text {tabel }} 2,000 H_{0}$ di tolak dan $\mathrm{H}_{\mathrm{a}}$ diterima. Kemudian diperoleh ratarata hasil belajar IPA pada kedua kelompok yaitu pada kelompok eksperimen $\bar{X}_{1}=82,05$ dan pada kelompok kontrol $\bar{X}_{2}=73,73$.Berdasarkan kriteria Penilaian Acuan Patokan (PAP) rata-rata kelompok eksperimen berada pada predikat Baik (B) yang berada pada rentang 80-89, sedangkan rata-rata kelompok kontrol berada pada predikat Cukup (C) yang berada pada rentang 65-79. Ini berarti bahwa model pembelajaran koopertif tipe $G I$ berbasis proyek berpengaruh terhadap hasil belajar IPA siswa kelas IV SD Gugus 1 Abiansemal. Hal ini berarti terdapat perbedaan yang signifikan hasil belajar IPA kelompok siswa yang dibelajarkan melalui model pembelajaran Koopertif Tipe GI berbasis proyek dengan kelompok siswa yang dibelajarkan melalui pembelajaran konvesional pada kelas IV SD Gugus 1 AbiansemalTahun Pelajaran 2016/2017.

Berdasarkan paparan tersebut, dapat dikatakan bahwa model pembelajaran Kooperatif tipe $G I$ berbasis proyekberpengaruh terhadap hasil belajar IPAsiswa kelas IV SD Gugus 1 AbiansemalTahun Pelajaran 2016/2017.

Terdapat beberapa saran yang dapat diajukan berdasarkan temuan dan kajian dalam penelitian ini adalah kepada.

a. Guru

Kepada guru disarankan agar lebih kreatif untuk memberikan fasilitas berupa sumber belajar dan kesempatan yang lebih besar bagi siswa pada pembelajaran dengan menggunakan model pembelajaran kooperatif tipe GI berbasis proyekdan dapat dijadikan alternatif dalam proses pembelajaran untuk membantu peserta didik meningkatkan hasil belajar IPA secara maksimal.

b. Sekolah

Kepada kepala sekolah disarankan agar dapat menggunakan hasil penelitian ini sebagai alternatif dalam mengelola pembelajaran agar sesuai dengan karakteristik pembelejaran IPA, sehingga mampu meningkatkan pengetahuan dan pemahaman peserta didik tentang IPA.

c. Peneliti Lain

Kepada peneliti disarankan agar hasil penelitian ini digunakan sebagai suatu acuan bagi peneliti lain untuk mengembangkan kemampuan diri dalam mempersiapkan diri sebagai calon pendidik dan meningkatkan pemahaman mengenai pembelajaran dengan penerapan model pembelajaran kooperatif tipe GI berbasis proyek.

\section{DAFTAR RUJUKAN}

Almuniar, Syamsiati \& Endang Uliyanti. 2015. Peningkatan Hasil Belajar Siswa Pada Pembelajaran Ipa Model Kooperatif Group Investigation di Sekolah Dasar. Jurnal Pendidikan dan Pembelajaran. Volume 4, Nomor 12

Amiruddin. 2014. Peningkatan Prestasi Belajar IPS Melalui Metode Pembelajaran Group Investigation Pada Siswa Kelas IV SDN 1 Tinauka. Jurnal Kreatif Tadulako Online. Voume 3, Nomor 4 (hlm. 163173)

Aziar. 2016. Peningkatan Kualitas Pembelajaran IPA Melalui Pembelajaran Kooperatif Tipe Group Investigation (GI) dengan Media CD Pembelajaran pada Siswa Kelas V SD Negeri Pengawu. Jurnal Kreatif Tadulako Online. Volume 4, Nomor 7 (hlm. 265-272)

Darmadi, Hamid. 2014. Metode Penelitian Pendidikan dan Sosial. Bandung: Alfabeta, cv.

Kosasih. 2016. Strategi Belajar dan Pembelajaran Implementasi Kurikulum 2013. Bandung: Yrama Widya

Kualitatif, dan R\&D). Bandung: Alfabeta

Kurniasih, Imas dan Sani, Berlin. 2016. Ragam Pengembangan Model Pembelajaran. Jakarta: Kata Pena 
Muliyantini, N.L.Pt. \& Dsk. Pt. Parmiti. 2017. Penerapan Model Pembelajaran Group Investigation (GI) untuk Meningkatkan Hasil Belajar IPA Kelas V. Jurnal Ilmiah Sekolah Dasar. Volume 1, Nomor 2 (hlm. 91-98)

Ngalimun,dkk. 2016. Strategi dan Model Pembelajaran. Yogyakarta:Aswaja Pressindo

Riasi, Putu, I Gede Raga \& I Made Suarjana. 2013. Penerapan Metode Group Investigation Melalui Kegiatan Keterampilan Tangan Untuk Meningkatkan Kemampuan Perkembangan Motorik Halus Anak di TK Bhakti Kumara Kalisada. Jurnal Mimbar PGSD Universitas Pendidikan Ganesha

Rusman. 2012. Model-model Pembelajaran. Jakarta: PT Raja Grapindo Persada

Samatowa, Usman. 2010. Pembelajaran IPA Di Sekolah Dasar. Jakarta: Indeks.

Sani, Ridwan Abddullah. 2014. Pembelajaran Saintifik untuk Implementasi Kurikulum 2013. Jakarta: PT Bumi Aksara

Sanjaya, Wina. 2010. Strategi Pembelajaran Berorientasi Standar Proses Pendidikan. Jakarta:Prenada Media Group

Setyosari, Punaji. 2013. Metode Pengembangan Pendidikan dan Pengembangan. Jakarta: Kencana Prenada Media Group

Suarni, Ni Ketut. 2014. "Pengaruh Pembelajaran Berbasis Proyek Terhadap Minat dan Hasil Belajar IPA Siswa Kelas V SD Gugus 1 Kecamatan Kuta”. Volume 4, tahun 2014. Pascasarjana, Universitas Pendidikan Ganesha. Tersedia pada http://pasca.undiksha.ac.id/ejournal/index.php/jurnal_pendas/article/view/1194 (diakses Minggu 22 Januari 2017)

Sugiyanto, Badrun Kartowagiran \& Jailani. Pengembangan Model Evaluasi Proses Pembelajaran Matematika di SMP Berdasarkan Kurikulum 2013. Jurnal Penelitian dan Evaluasi Pendidikan. Volume 19, Nomor 1 (hlm. 82-95)

Sugiyono . 2014. Metode Penelitian Pendidikan (Pendekatan Kuantitatif,

Sugiyono. 2013. Statistika Untuk Penelitian. Bandung: Alfabeta

Suharsimi, Arikuonto. 2012. Dasar-Dasar Evaluasi Pendidikan. Jakarta: Bumi Aksara

Susanti, Ni Pt. Yusi, I Wyn. Darsana \& I Kt. Ardana. 2013. Pengaruh Model Pembelajaran Kooperatif Tipe Group Investigation Berdasarkan Keterampilan Proses Terhadap Hasil Belajar IPA Siswa Kelas IV SD Gugus 2 Mengwi. Jurnal PGSD Universitas Pendidikan Ganesha

Susanto, Ahmad. 2015. Teori Belajar dan Pembelajaran di Sekolah Dasar. Jakarta: Kencana Predana Media Group

Sutrini, Ni Ngh., Ni Kt. Suarni \& Ndara Tanggu Renda. 2013. Pengaruh Model Pembelajaran Kooperatif Tipe Group Investigation (GI) Terhadap Hasil Belajar IPA Siswa Kelas V SD di Gugus 7 Tianyar. Jurnal PGSD Universitas Pendidikan Ganesha

Taniredja, dkk. 2012. Model-model Pembelajaran Inovatif. Bandung: Alfabeta, cv.

Undang-Undang Republik Indonesia Nomor 20 Tahun 2003 Tentang Sistem Pendidikan Nasional

Universitas Pendidikan Ganesha. 2014. Pedoman Penulisan Skripsi dan Tugas Akhir. Singaraja: UNDIKSHA.

Wardana, I Wyn. Setia, Ni Md. Setuti \& I Gd. Wawan Sudatha. 2013. Pengaruh Model Pembelajaran Group Investigation Berbantuan Asesmen Proyek Terhadap Prestasi Belajar IPA Siswa Kelas V Sekolah Dasar Gugus III Tampaksiring. Jurnal Mimbar PGSD Universitas Pendidikan Ganesha

Wiryarta, Nyoman Saka Ni Ketut. 2014. "Model Pembelajaran Kooperatif Tipe Group Investigation Berbasis Penilaian ProyekBerpengaruh Terhadap Hasil Belajar IPA Siswa Kelas V SD Gugus SrikandiDenpasar Timur". Volume 2, tahun 2014. Jurusan Pendidikan Guru Sekolah Dasar. Universitas $\quad$ Pendidikan Ganesha. Tersedia padahttp://ejournal.undiksha.ac.id/index.php/JPGSD/article/view/1949 (diakses Senin, 2 Januari 2017) 
Wisnawa, I Dewa Gede Raka, Ndara Tanggu Renda \& I Wayan Widiana. 2016. Penerapan Model Pembelajaran GI (Group Investigation) Untuk Meningkatkan Hasil Belajar IPA Kelas IV. e-Journal PGSD Universitas Pendidikan Ganesha. Volume 6, Nomor 3

Wulandari, Andhika Ayu. 2010. Efektifitas Penggunaan Metode Group Investigation dan Brainstorming Terhadap Prestasi Belajar Matematika Siswa Kelas V Sekolah Dasar Negeri Se-Kecamatan Laweyan Pada Pokok Bahasan Sifat-Sifat Bangun Datar ditinjau Dari Aktivitas Belajar Siswa. Pusat Dokumentasi dan Informasi Ilmiah Universitas Sebelas Maret

Yusuf, Muri. 2015. Asesmen dan Evaluasi Pendidikan. Jakarta: Prenada Media Group

Zainuddin, H. M. 2013. Implementasi Pembentukkan Karakter Bersahabat Melalui Model Pembelajaran Group Investigation. Mimbar Jurnal Sosial dan Pembangunan. Volume 29, Nomor 1 (hlm. 69-76) 